Article

\title{
Preparation and Characterization of Porous $\mathrm{Ti} / \mathrm{SnO}_{2}-\mathrm{Sb}_{2} \mathrm{O}_{3} / \mathrm{PbO}_{2}$ Electrodes for the Removal of Chloride Ions in Water
}

\author{
Kangdong $\mathrm{Xu}{ }^{1}$, Jianghua Peng ${ }^{2}$, Pan Chen ${ }^{1}$, Wankai Gu ${ }^{1}$, Yunbai Luo ${ }^{1}$ and Ping Yu ${ }^{1, *}$ \\ 1 College of Chemistry and Molecular Sciences, Wuhan University, Wuhan 430072, China; \\ xukangdong0520@163.com (K.X.); 2016202030162@whu.edu.cn (P.C.); wiki_gu@163.com (W.G.); \\ ybai@whu.edu.cn (Y.L.) \\ 2 MOE Key Laboratory of Thermo-Fluid Science and Engineering, Xi'an Jiaotong University, Xi'an 710049, \\ China; pengke112@126.com \\ * Correspondence: yuping@whu.edu.cn; Tel.: +86-027-6875-2511
}

Received: 14 September 2019; Accepted: 14 October 2019; Published: 18 October 2019

\begin{abstract}
Porous Ti/SnO ${ }_{2}-\mathrm{Sb}_{2} \mathrm{O}_{3} / \mathrm{PbO}_{2}$ electrodes for electrocatalytic oxidation of chloride ions were studied by exploring the effects of different operating conditions, including pore size, initial concentration, current density, initial $\mathrm{pH}$, electrode plate spacing, and the number of cycles. In addition, a physicochemical characterization and an electrochemical characterization of the porous $\mathrm{Ti} / \mathrm{SnO}_{2}-\mathrm{Sb}_{2} \mathrm{O}_{3} / \mathrm{PbO}_{2}$ electrodes were performed. The results showed that Ti/SnO $\mathrm{S}_{2}-\mathrm{Sb}_{2} \mathrm{O}_{3} / \mathrm{PbO}_{2}$ electrodes with $150 \mu \mathrm{m}$ pore size had the best removal effect on chloride ions with removal ratios amounting up to $98.5 \%$ when the initial concentration was $10 \mathrm{~g} \mathrm{~L}^{-1}$, the current density $125 \mathrm{~mA} \mathrm{~cm}^{-2}$, the initial $\mathrm{pH}=9$, and the electrode plate spacing $0.5 \mathrm{~cm}$. The results, moreover, showed that the oxygen evolution potential of $150 \mu \mathrm{m}$ porous $\mathrm{Ti} / \mathrm{SnO}_{2}-\mathrm{Sb}_{2} \mathrm{O}_{3} / \mathrm{PbO}_{2}$ electrodes was highest, which minimized side reactions involving oxygen formation and which increased the removal effect of chloride ions.
\end{abstract}

Keywords: electrocatalytic oxidation; chloride ions removal ratio; the porous electrode; influencing factors

\section{Introduction}

In recent years, China has raised the level of environmental protection, which requires industrial wastewaters not to be discharged from various enterprises. Therefore, in order to ensure the normal operation of its own production, each enterprise must realize the recycling of water. At present, the commonly used method is to properly dispose of the drainage and then replenish it into the industrial water system. However, various ions are continuously enriched in the water when the water is reused, which causes various adverse effects on the operation of equipment. The amount of scale cations (such as calcium ions and magnesium ions, etc.) in water can be reduced by changing the $\mathrm{pH}$ of the water body and by inducing flocculation sedimentation [1], but there is no effective method of reducing anions (such as chloride ions) which have corrosive effects on equipment in water [2]. Therefore, there is a need to find a way to quickly and easily reduce chloride ions in water.

At present, the methods for removing chloride ions include biological [3,4], reverse osmosis $[5,6]$, distillation, multi-effect evaporation [7], electrodialysis [8-10], and ions exchange methods. The biological method involves high operating costs, while the removal effect does not work well. The reverse osmosis method is burdened by high consumption of acid and alkali as well as energy consumption. The distillation method and the multi-effect evaporation methods involve high energy consumption. The electrodialysis method involves high operation voltages, and membranes are easily 
contaminated. The ion exchange method is expensive and tends to cause secondary pollution during the elution process. The electrocatalytic oxidation technology is a new method for removing chloride ions, which has the advantages of high efficiency in removing chloride ions, simple process, simple operation, and low operating cost, and there are few related studies.

In this study, porous $\mathrm{Ti} / \mathrm{SnO}_{2}-\mathrm{Sb}_{2} \mathrm{O}_{3} / \mathrm{PbO}_{2}$ electrodes were studied and it was found that these have a significant effect on electrocatalytic oxidation of removing chloride ions. Self-made porous $\mathrm{Ti} / \mathrm{SnO}_{2}-\mathrm{Sb}_{2} \mathrm{O}_{3} / \mathrm{PbO}_{2}$ electrodes with different pore sizes were used as anodes to construct an electrolyzer. The high potential of the anode and unique catalytic oxidation characteristics of the surface coating were used for removing chloride ions. Three different kinds of porous $\mathrm{Ti} / \mathrm{SnO}_{2}-\mathrm{Sb}_{2} \mathrm{O}_{3} / \mathrm{PbO}_{2}$ electrodes were prepared and characterized systematically with regard to morphology, crystal structure, and various electrochemical performances. $\mathrm{NaCl}$ solutions were used for simulating chlorine-containing wastewaters for studying the effects of initial concentration, pore size, current density, initial $\mathrm{pH}$, electrode plate spacing, and the number of cycles. The results showed that the porous $\mathrm{Ti} / \mathrm{SnO}_{2}-\mathrm{Sb}_{2} \mathrm{O}_{3} / \mathrm{PbO}_{2}$ electrodes were efficiently reducing the number of chloride ions in water, thus providing a practical method of removing chloride ions from water.

\section{Experimental}

\subsection{Materials and Reagents}

The substrates used in this study were commercial samples of porous Ti $(20 \mathrm{~mm} \times 10 \mathrm{~mm} \times 1 \mathrm{~mm})$, which had average pore sizes of $50 \mu \mathrm{m}, 100 \mu \mathrm{m}$, and $150 \mu \mathrm{m}$. In regard to removing chloride ions, porous Ti substrates with larger pore sizes do not meet the requirements for removing chloride ions in terms of hardness, our studies were restricted to the three pore sizes mentioned above. In this paper, all chemicals were analytical grade without any other impurities. $\mathrm{SnCl}_{4} \cdot 5 \mathrm{H}_{2} \mathrm{O}, \mathrm{SbCl}_{3}, \mathrm{HCl}$, $\mathrm{Pb}\left(\mathrm{NO}_{3}\right)_{2}, \mathrm{Cu}\left(\mathrm{NO}_{3}\right)_{2} \cdot 3 \mathrm{H}_{2} \mathrm{O}, \mathrm{NaF}, \mathrm{HNO}_{3}, \mathrm{NaOH}, \mathrm{H}_{2} \mathrm{C}_{2} \mathrm{O}_{4}, \mathrm{NaCl}$, and other chemicals were obtained from Shanghai Wo Kai Biotechnology Co., Ltd. (Shanghai, China). All the solutions used in these experiments were prepared with deionized water. For the simulation of chloride ion contaminated waste waters, $\mathrm{NaCl}$ solutions were used.

\subsection{Electrode Preparation}

First, at a temperature of $70{ }^{\circ} \mathrm{C}$, porous Ti substrates $(50 \mu \mathrm{m}, 100 \mu \mathrm{m}$, and $150 \mu \mathrm{m})$ were heated in sodium hydroxide $(20 \% \mathrm{~m} \%)$ for $1 \mathrm{~h}$ to remove all traces of oil on the surface and were then washed in deionized water. Thereafter, the porous Ti substrates were etched in oxalic acid $(15 \% \mathrm{~m} \%)$ at a temperature of $85^{\circ} \mathrm{C}$ for $1 \mathrm{~h}$ to obtain a uniformly rough surface. Finally, the samples were washed in deionized water and stored in deionized water [11,12].

Second, the coating solution, consisting of $1.20 \mathrm{~g} \mathrm{SnCl}_{4} \cdot 5 \mathrm{H}_{2} \mathrm{O}$ and $0.20 \mathrm{~g} \mathrm{SbCl}_{3}$ was dissolved in $40 \mathrm{~mL}$ ethanol, and $1 \mathrm{~mL}$ of concentrated hydrochloric acid was added. The treated porous $\mathrm{Ti}$ substrates were immersed in the coating solution for $5 \mathrm{~min}$, and then dried at about $120^{\circ} \mathrm{C}$ for $15 \mathrm{~min}$, and thereafter calcined at $500{ }^{\circ} \mathrm{C}$ for $20 \mathrm{~min}$ in a muffle furnace. All above processes were repeated ten times and the electrodes were annealed at $500{ }^{\circ} \mathrm{C}$ for $60 \mathrm{~min}$ in the last process $[13,14]$. Finally, the porous $\mathrm{Ti} / \mathrm{SnO}_{2}-\mathrm{Sb}_{2} \mathrm{O}_{3}$ electrode was prepared.

Third, the deposition solution consisted of $40 \mathrm{~g} \mathrm{~Pb}\left(\mathrm{NO}_{3}\right)_{2}, 15 \mathrm{~g} \mathrm{Cu}\left(\mathrm{NO}_{3}\right)_{2} \cdot 3 \mathrm{H}_{2} \mathrm{O}, 0.5 \mathrm{~g} \mathrm{NaF}$, and $0.1 \mathrm{M} \mathrm{HNO}_{3}$. The porous $\mathrm{Ti} / \mathrm{SnO}_{2}-\mathrm{Sb}_{2} \mathrm{O}_{3}$ electrodes were used as anodes and a pure titanium plate as a cathode. The current density was $5 \mathrm{~mA} \mathrm{~cm}{ }^{-2}$ and the $\mathrm{PbO}_{2}$ was deposited on the porous $\mathrm{Ti} / \mathrm{SnO}_{2}-\mathrm{Sb}_{2} \mathrm{O}_{3}$ electrode at $65{ }^{\circ} \mathrm{C}$ for $0.5 \mathrm{~h}$ under stirring conditions. Finally, the prepared porous Ti/ $/ \mathrm{SnO}_{2}-\mathrm{Sb}_{2} \mathrm{O}_{3} / \mathrm{PbO}_{2}$ electrodes were washed in deionized water [15-17].

\subsection{Electrode Characterization}

The surface morphologies of porous $\mathrm{Ti} / \mathrm{SnO}_{2}-\mathrm{Sb}_{2} \mathrm{O}_{3} / \mathrm{PbO}_{2}$ electrodes were characterized by Field Emission Scanning Electron Microscopy (Zeiss SIGMA, Carl Zeiss Corporation, Jena, Germany). The 
composition and the chemical state of the porous $\mathrm{Ti} / \mathrm{SnO}_{2}-\mathrm{Sb}_{2} \mathrm{O}_{3} / \mathrm{PbO}_{2}$ electrode was determined by an X-ray photoelectron spectrometer (ESCALAB250Xi, Thermo Fisher Scientific, Waltham, MA, USA). The crystal structure of porous $\mathrm{Ti} / \mathrm{SnO}_{2}-\mathrm{Sb}_{2} \mathrm{O}_{3} / \mathrm{PbO}_{2}$ electrodes were determined by an $\mathrm{X}$-ray Diffractometer (XRD-6100, Shimadzu Corporation, Kyoto, Japan) with $\mathrm{Cu}-\mathrm{K} \alpha(\lambda=0.154 \mathrm{~nm})$ incident radiation at a scanning rate of $2 \mathrm{~min}^{-1}$ in $2 \theta$ mode from 20 to 90 .

The electrochemical characterization including linear sweep voltammetry (LSV) curves and cyclic voltammetry of porous $\mathrm{Ti} / \mathrm{SnO}_{2}-\mathrm{Sb}_{2} \mathrm{O}_{3} / \mathrm{PbO}_{2}$ electrodes were carried out using a CHI760E electrochemical workstation ( $\mathrm{CH}$ Instruments, Chenhua Co., Shanghai, China) with a conventional three-electrode cell. The working electrode was the $\mathrm{PbO}_{2}$ electrode; the reference electrode was a saturated calomel electrode (SCE) and a platinum electrode served as a counter electrode.

\subsection{Electrocatalytic Oxidation of Chloride Ions}

The porous Ti/ $\mathrm{SnO}_{2}-\mathrm{Sb}_{2} \mathrm{O}_{3} / \mathrm{PbO}_{2}$ electrodes were used as anodes and a Ti electrode as the cathode. The produced chlorine was absorbed in an absorption tank. After the reaction, $\mathrm{AgNO}_{3}$ solution was used as a titrant and $\mathrm{K}_{2} \mathrm{CrO}_{4}$ solution as a color developer. In order to obtain optimal removal conditions, the effects of the following factors were considered for electrocatalytic oxidation of chloride ions, including initial concentration (from $5 \mathrm{~g} \mathrm{~L}^{-1}$ to $25 \mathrm{~g} \mathrm{~L}^{-1}$ ), pore size (from $50 \mu \mathrm{m}$ to $150 \mu \mathrm{m}$ ), current densities (from $50 \mathrm{~mA} \mathrm{~cm}^{-2}$ to $125 \mathrm{~mA} \mathrm{~cm}^{-2}$ ), initial $\mathrm{pH}$ (from 3 to 11), and electrode plate spacing (from $0.5 \mathrm{~cm}$ to $1 \mathrm{~cm}$ ). The removal ratio of chloride ions was calculated as follows:

$$
\text { Removal ratios of chloride ions }=\frac{B_{1}-B_{2}}{B_{1}} \times 100 \%
$$

$B_{1}$ is the concentration of the original chloride ions in the $\mathrm{NaCl}$ solution, and $B_{2}$ the concentration of the remaining chloride ions in the $\mathrm{NaCl}$ solution after the reaction.

\section{Results and Discussion}

\subsection{Physicochemical Characterization}

\subsubsection{Scanning Electron Microscopy (SEM) Characterization}

In Figure 1, the scanning electron microscopy (SEM) images of the three different pore sizes $(50 \mu \mathrm{m}, 100 \mu \mathrm{m}$, and $150 \mu \mathrm{m})$ are shown. As shown in Figure 1a,d,g, the surfaces of the porous Ti substrates are very rough. Figure $1 \mathrm{~b}, \mathrm{e}$, h show that the porous $\mathrm{Ti} / \mathrm{SnO}_{2}-\mathrm{Sb}_{2} \mathrm{O}_{3}$ electrodes still have a lot of irregular pores, which indicates that the porous $\mathrm{Ti} / \mathrm{SnO}_{2}-\mathrm{Sb}_{2} \mathrm{O}_{3}$ electrodes have large specific surface areas. By zooming 500 and 4000 times, it is seen that the $\mathrm{SnO}_{2}-\mathrm{Sb}_{2} \mathrm{O}_{3}$ intermediate layers are uniformly distributed and crack-free, which is beneficial for prolonging the service life of the electrode. Figure $1 \mathrm{c}$, f,i show that the porous $\mathrm{Ti} / \mathrm{SnO}_{2}-\mathrm{Sb}_{2} \mathrm{O}_{3} / \mathrm{PbO}_{2}$ electrodes still have many irregular pores. Although some of the pores became during electrodeposition, large specific surface areas were still retained compared to the planar electrodes. By zooming 500 and 4000 times, it is revealed that the $\mathrm{PbO}_{2}$ grains are also very compact and evenly distributed. In short, the porous $\mathrm{Ti} / \mathrm{SnO}_{2}-\mathrm{Sb}_{2} \mathrm{O}_{3} / \mathrm{PbO}_{2}$ electrodes have large surface areas, which can provide many active sites for electrochemical oxidation [18]. 

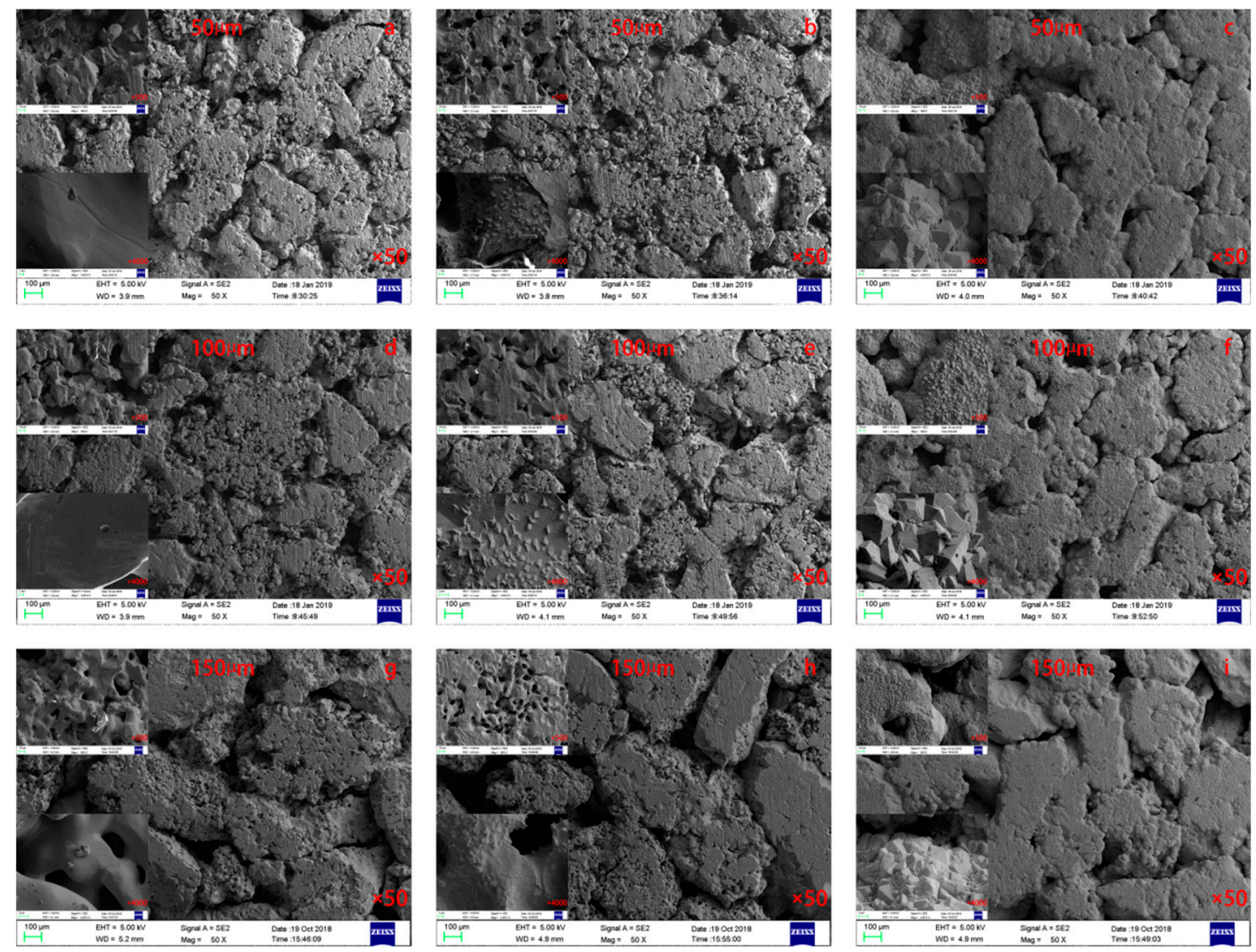

Figure 1. Scanning electron microscopy (SEM) images: (a) $50 \mu \mathrm{m}$ porous Ti substrate; (b) $50 \mu \mathrm{m}$ porous $\mathrm{Ti} / \mathrm{SnO}_{2}-\mathrm{Sb}_{2} \mathrm{O}_{3}$ electrode; (c) $50 \mu \mathrm{m}$ porous $\mathrm{Ti} / \mathrm{SnO}_{2}-\mathrm{Sb}_{2} \mathrm{O}_{3} / \mathrm{PbO}_{2}$ electrode; (d) $100 \mu \mathrm{m}$ porous Ti substrate; (e) $100 \mu \mathrm{m}$ porous $\mathrm{Ti} / \mathrm{SnO}_{2}-\mathrm{Sb}_{2} \mathrm{O}_{3}$ electrode; (f) $100 \mu \mathrm{m}$ porous $\mathrm{Ti} / \mathrm{SnO}_{2}-\mathrm{Sb}_{2} \mathrm{O}_{3} / \mathrm{PbO}_{2}$ electrode; (g) $150 \mu \mathrm{m}$ porous Ti substrate; (h) $150 \mu \mathrm{m}$ porous $\mathrm{Ti} / \mathrm{SnO}_{2}-\mathrm{Sb}_{2} \mathrm{O}_{3}$ electrode; (i) $150 \mu \mathrm{m}$ porous $\mathrm{Ti} / \mathrm{SnO}_{2}-\mathrm{Sb}_{2} \mathrm{O}_{3} / \mathrm{PbO}_{2}$ electrode.

\subsubsection{X-ray Photoelectron Spectrometer (XPS) Characterization}

In order to investigate the chemical state of each element in the porous $\mathrm{Ti} / \mathrm{SnO}_{2}-\mathrm{Sb}_{2} \mathrm{O}_{3} / \mathrm{PbO}_{2}$ electrodes, the electrodes were analyzed by XPS. Since the XPS spectra of the three different-pore-size electrodes are the same, only the $150 \mu \mathrm{m}$ porous $\mathrm{Ti} / \mathrm{SnO}_{2}-\mathrm{Sb}_{2} \mathrm{O}_{3} / \mathrm{PbO}_{2}$ electrode is analyzed here. Figure $2 \mathrm{a}$ is the full spectrum of a porous $\mathrm{Ti} / \mathrm{SnO}_{2}-\mathrm{Sb}_{2} \mathrm{O}_{3} / \mathrm{PbO}_{2}$ electrode. It can be seen that there are mainly $\mathrm{Ti}, \mathrm{Sn}, \mathrm{Sb}, \mathrm{O}, \mathrm{Pb}$, and $\mathrm{C}$ peaks in the whole electrode. Figure $2 \mathrm{~b}$ shows the $\mathrm{Sn} 3 \mathrm{~d}$ spectrum with two characteristic peaks at $487.1 \mathrm{eV}$ and $495.5 \mathrm{eV}$. Figure 2c shows the $\mathrm{Sb} 3 \mathrm{~d}$ and $\mathrm{O} 1 \mathrm{~s}$ spectra with characteristic peaks at $540.3 \mathrm{eV}$ and $531.6 \mathrm{eV}$. Figure $2 \mathrm{~d}$ shows the $\mathrm{Pb} 4 \mathrm{f}$ spectrum with characteristic peaks at $138.8 \mathrm{eV}$ and $143.7 \mathrm{eV}$. The composition and chemical state of the porous $\mathrm{Ti} / \mathrm{SnO}_{2}-\mathrm{Sb}_{2} \mathrm{O}_{3} / \mathrm{PbO}_{2}$ electrode could be determined by the XPS characterization results, and it was inferred that porous $\mathrm{Ti} / \mathrm{SnO}_{2}-\mathrm{Sb}_{2} \mathrm{O}_{3} / \mathrm{PbO}_{2}$ electrode was successfully prepared. 

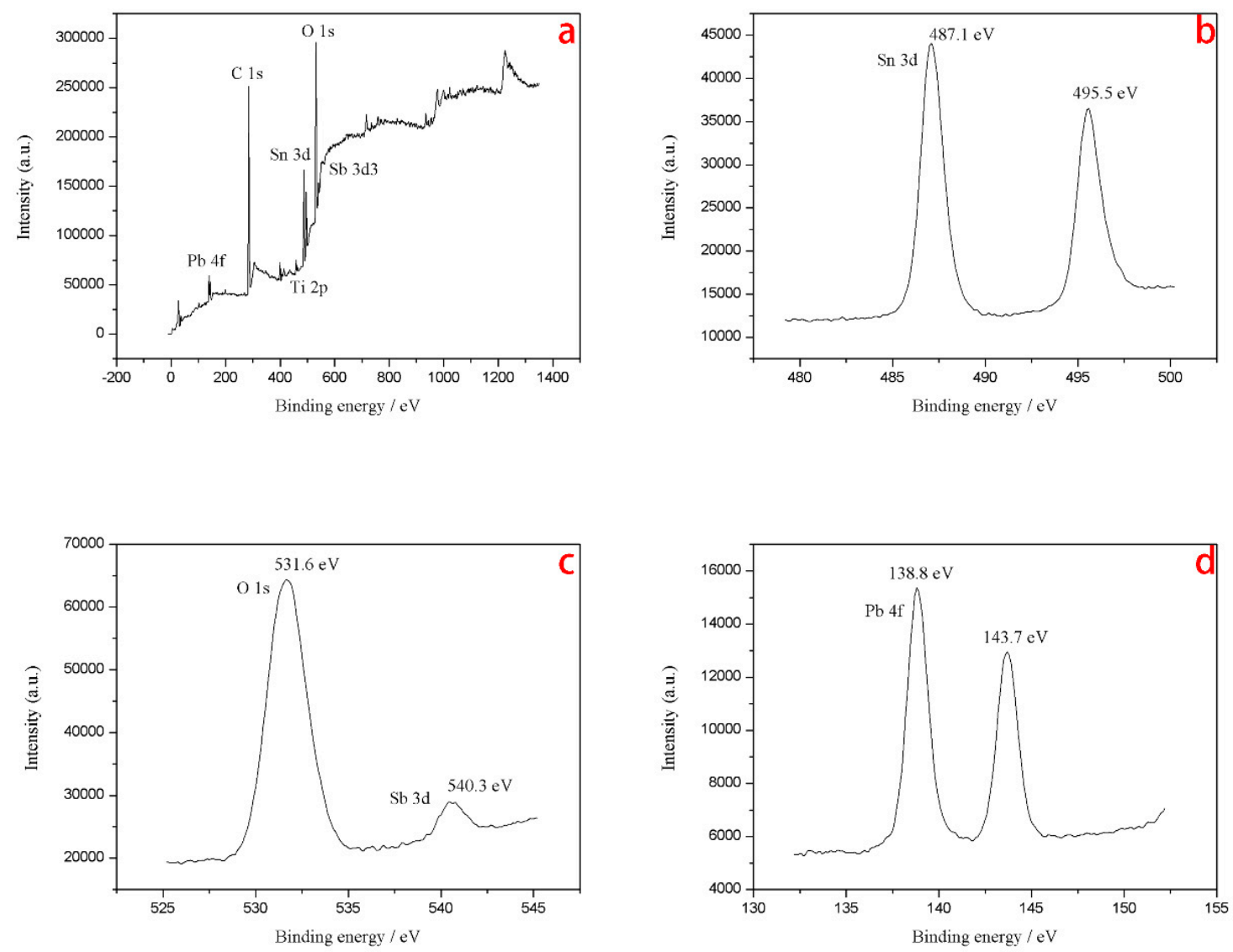

Figure 2. (a) XPS spectrum of the porous $\mathrm{Ti} / \mathrm{SnO}_{2}-\mathrm{Sb}_{2} \mathrm{O}_{3} / \mathrm{PbO}_{2}$ electrode; (b) XPS spectrum of $\mathrm{Sn} 3 \mathrm{~d}$; (c) XPS spectrum of $\mathrm{O} 1 \mathrm{~s}$ and $\mathrm{Sb} 3 \mathrm{~d}$; (d) XPS spectrum of $\mathrm{Pb} 4 \mathrm{f}$.

\subsubsection{X-ray Diffraction (XRD) Characterization}

To further verify the results, the XRD patterns of the electrode coatings prepared on the three different-pore-size Ti substrates are shown in Figure 3. Since the XRD images of the three pore sizes electrodes are the same, only the $150 \mu \mathrm{m}$ porous $\mathrm{Ti} / \mathrm{SnO}_{2}-\mathrm{Sb}_{2} \mathrm{O}_{3} / \mathrm{PbO}_{2}$ electrodes are analyzed here. Figure 3 shows the $\beta-\mathrm{PbO}_{2}$ diffraction peaks, which are (110), (101), (200), (211), (220), (310), (301), (321), (312), and (411). At the same time, Figure 3 shows the weak $\alpha-\mathrm{PbO}_{2}$ diffraction peaks, which is (041). In addition, there are no diffraction peaks of $\mathrm{Ti}, \mathrm{SnO}_{2}$, and $\mathrm{Sb}_{2} \mathrm{O}_{3}$, which proves that the $\mathrm{PbO}_{2}$ coating had completely covered the porous $\mathrm{Ti} / \mathrm{SnO}_{2}-\mathrm{Sb}_{2} \mathrm{O}_{3}$ electrodes. 


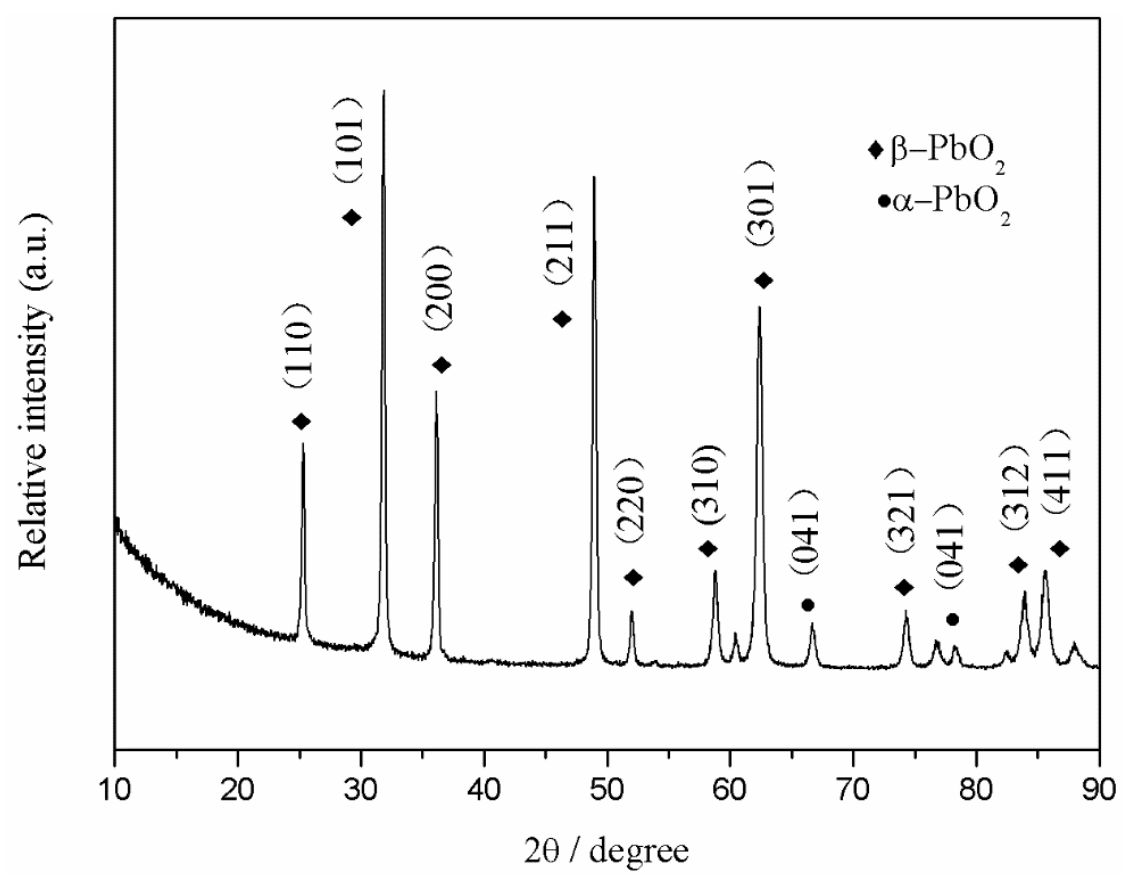

Figure 3. The X-ray diffraction (XRD) pattern of $150 \mu \mathrm{m}$ porous $\mathrm{Ti} / \mathrm{SnO}_{2}-\mathrm{Sb}_{2} \mathrm{O}_{3} / \mathrm{PbO}_{2}$ electrode.

\subsection{Electrochemical Characterization}

\subsubsection{Linear Sweep Voltammetry (LSV) Curves}

Figure 4 shows the linear sweep voltammetry (LSV) curves of the three different kinds of porous $\mathrm{Ti} / \mathrm{SnO}_{2}-\mathrm{Sb}_{2} \mathrm{O}_{3} / \mathrm{PbO}_{2}$ electrodes as obtained in a $0.5 \mathrm{~mol} \mathrm{~L}^{-1} \mathrm{H}_{2} \mathrm{SO}_{4}$ solution at a scan rate of $5 \mathrm{mV} \mathrm{s}^{-1}$. The result shows that the oxygen evolution potential is $2.02 \mathrm{~V}, 1.99 \mathrm{~V}$, and $1.96 \mathrm{~V}$ at the $150 \mu \mathrm{m}$, $100 \mu \mathrm{m}$, and $50 \mu \mathrm{m}$ porous electrodes, respectively. High oxygen evolution potentials indicate that side reactions involving the formation of oxidized species are not very likely to occur [19]. $150 \mu \mathrm{m}$ porous $\mathrm{Ti} / \mathrm{SnO}_{2}-\mathrm{Sb}_{2} \mathrm{O}_{3} / \mathrm{PbO}_{2}$ electrodes therefore have the best removal effect on chloride ions.

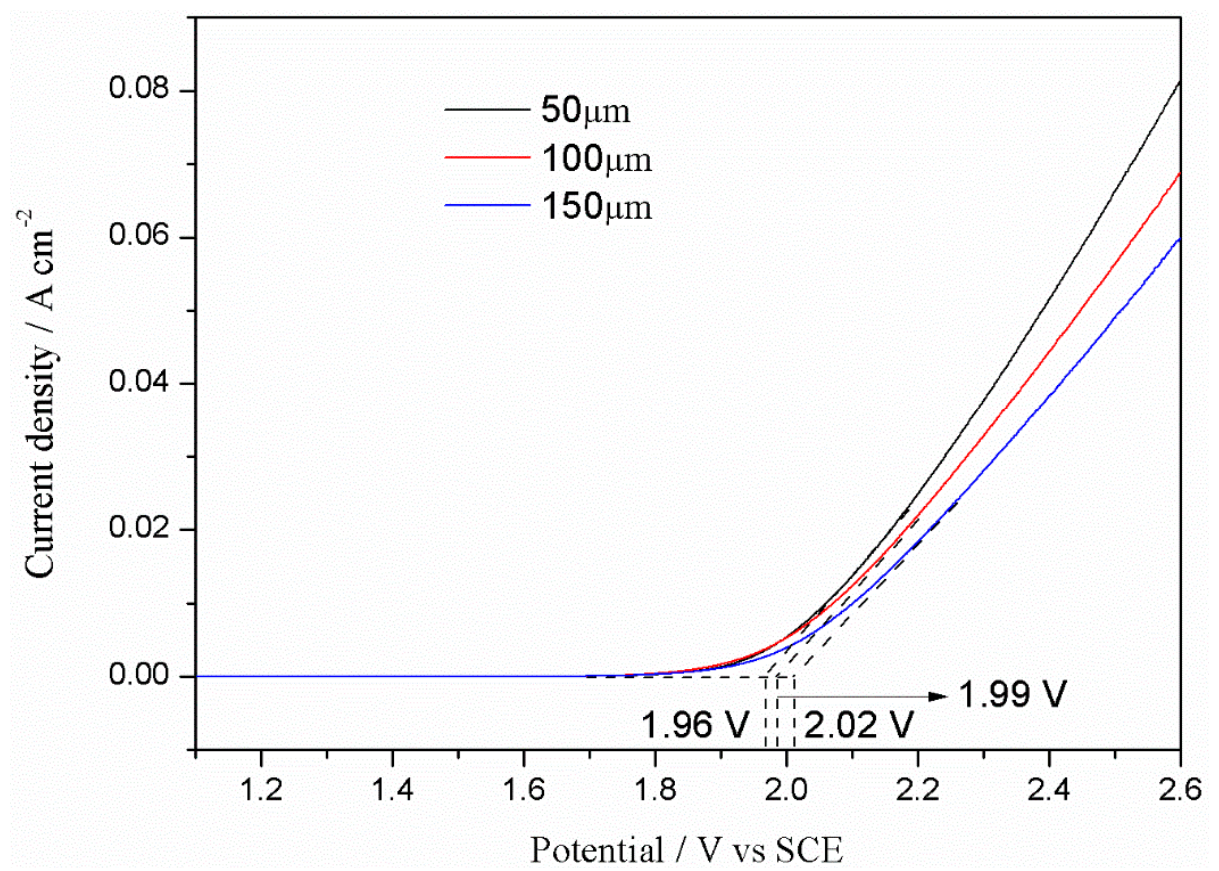

Figure 4. Linear sweep voltammetry (LSV) curves of porous $\mathrm{Ti} / \mathrm{SnO}_{2}-\mathrm{Sb}_{2} \mathrm{O}_{3} / \mathrm{PbO}_{2}$ electrodes in $0.5 \mathrm{~mol} \mathrm{~L}^{-1} \mathrm{H}_{2} \mathrm{SO}_{4}$ solution at a scan rate of $5 \mathrm{mV} \mathrm{s}^{-1}$. 


\subsubsection{Cyclic Voltammetry}

Figure 5 shows the cyclic voltammetry of the three different-pore-size Ti/ $\mathrm{SnO}_{2}-\mathrm{Sb}_{2} \mathrm{O}_{3} / \mathrm{PbO}_{2}$ electrodes in $0.5 \mathrm{~mol} \mathrm{~L}^{-1} \mathrm{H}_{2} \mathrm{SO}_{4}$ solution at a scan rate of $5 \mathrm{mV} \mathrm{s}^{-1}$. The results show that the redox peak of the $50 \mu \mathrm{m}$ porous $\mathrm{Ti} / \mathrm{SnO}_{2}-\mathrm{Sb}_{2} \mathrm{O}_{3} / \mathrm{PbO}_{2}$ electrode is highest, while it is lowest at the $150 \mu \mathrm{m}$ porous $\mathrm{Ti} / \mathrm{SnO}_{2}-\mathrm{Sb}_{2} \mathrm{O}_{3} / \mathrm{PbO}_{2}$ electrode. The low oxygen evolution potential of the $50 \mu \mathrm{m}$ porous $\mathrm{Ti} / \mathrm{SnO}_{2}-\mathrm{Sb}_{2} \mathrm{O}_{3} / \mathrm{PbO}_{2}$ electrode indicates that it has a high areal density of oxygen evolution sites. The high oxygen evolution potential of the $150 \mu \mathrm{m}$ porous $\mathrm{Ti} / \mathrm{SnO}_{2}-\mathrm{Sb}_{2} \mathrm{O}_{3} / \mathrm{PbO}_{2}$ electrode, on the other hand, indicates a low areal density of oxygen evolution sites, which is beneficial for the electrocatalytic oxidation of chloride ions [20].

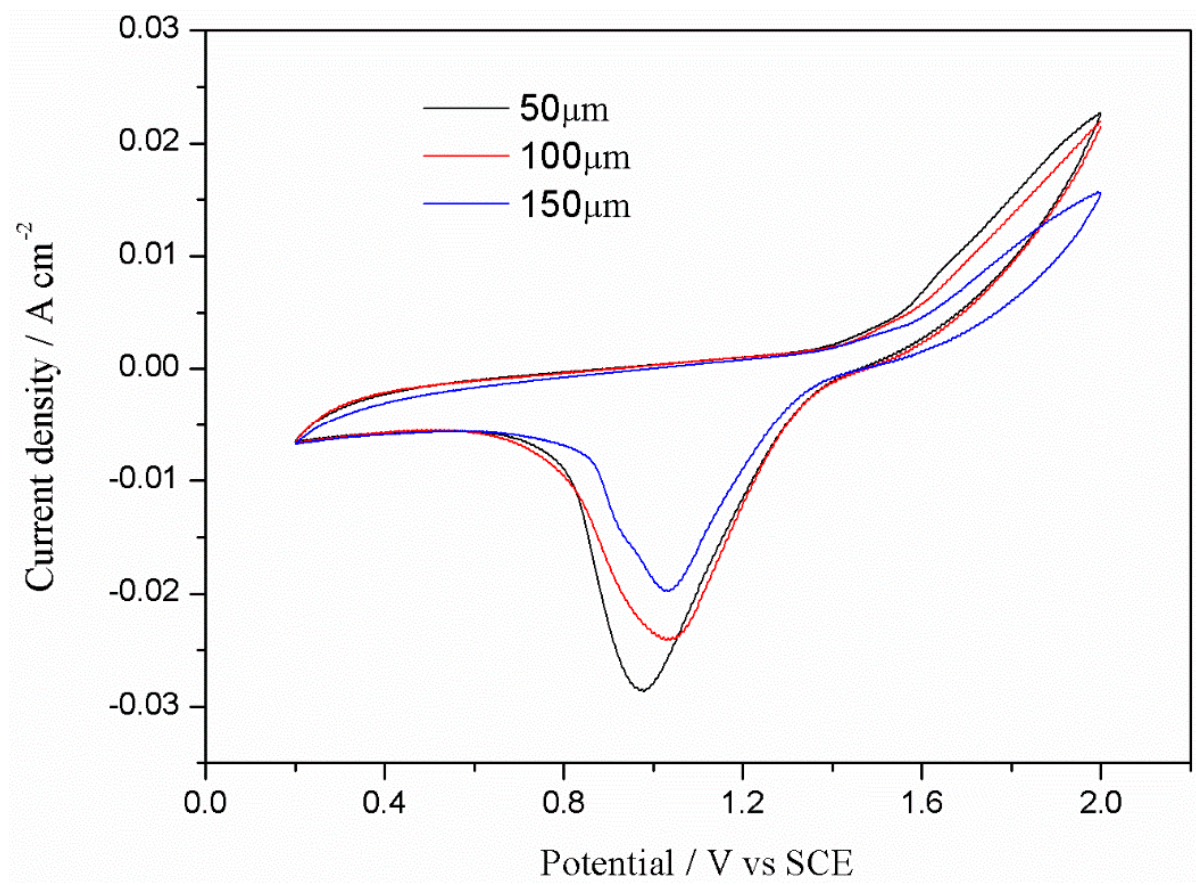

Figure 5. Cyclic voltammetry curve of porous $\mathrm{Ti} / \mathrm{SnO}_{2}-\mathrm{Sb}_{2} \mathrm{O}_{3} / \mathrm{PbO}_{2}$ electrodes in $0.5 \mathrm{~mol} \mathrm{~L}{ }^{-1} \mathrm{H}_{2} \mathrm{SO}_{4}$ solution at a scan rate of $5 \mathrm{mV} \mathrm{s}^{-1}$.

\subsubsection{Linear Sweep Voltammetry (LSV) Curves in Different pH Solutions}

Figure 6 shows the LSV curves of a $150 \mu$ m porous $\mathrm{Ti} / \mathrm{SnO}_{2}-\mathrm{Sb}_{2} \mathrm{O}_{3} / \mathrm{PbO}_{2}$ electrode in different $\mathrm{pH}$ solutions at a scan rate of $5 \mathrm{mV} \mathrm{s}^{-1}$. Solutions with $\mathrm{pH}$ values between $\mathrm{pH}=3$ and $\mathrm{pH}=5$ were prepared from buffer solution of citric acid and sodium citrate, and solutions with $\mathrm{pH}=7$ from buffer solution of potassium monohydrogen phosphate and potassium dihydrogen phosphate. Solutions with $\mathrm{pH}$ values between $\mathrm{pH}=9$ and $\mathrm{pH}=11$, finally, were composed from sodium carbonate and sodium bicarbonate buffer solution. It can be seen from the Figure 6 that under the same voltage conditions, the current density is smallest at $\mathrm{pH}=9$, which indicates that oxygen evolution is least likely to occur under these conditions and that therefore $150 \mu \mathrm{m}$ porous $\mathrm{Ti} / \mathrm{SnO}_{2}-\mathrm{Sb}_{2} \mathrm{O}_{3} / \mathrm{PbO}_{2}$ electrodes will exhibit an optimum chloride ion removal effect at $\mathrm{pH}=9$. 


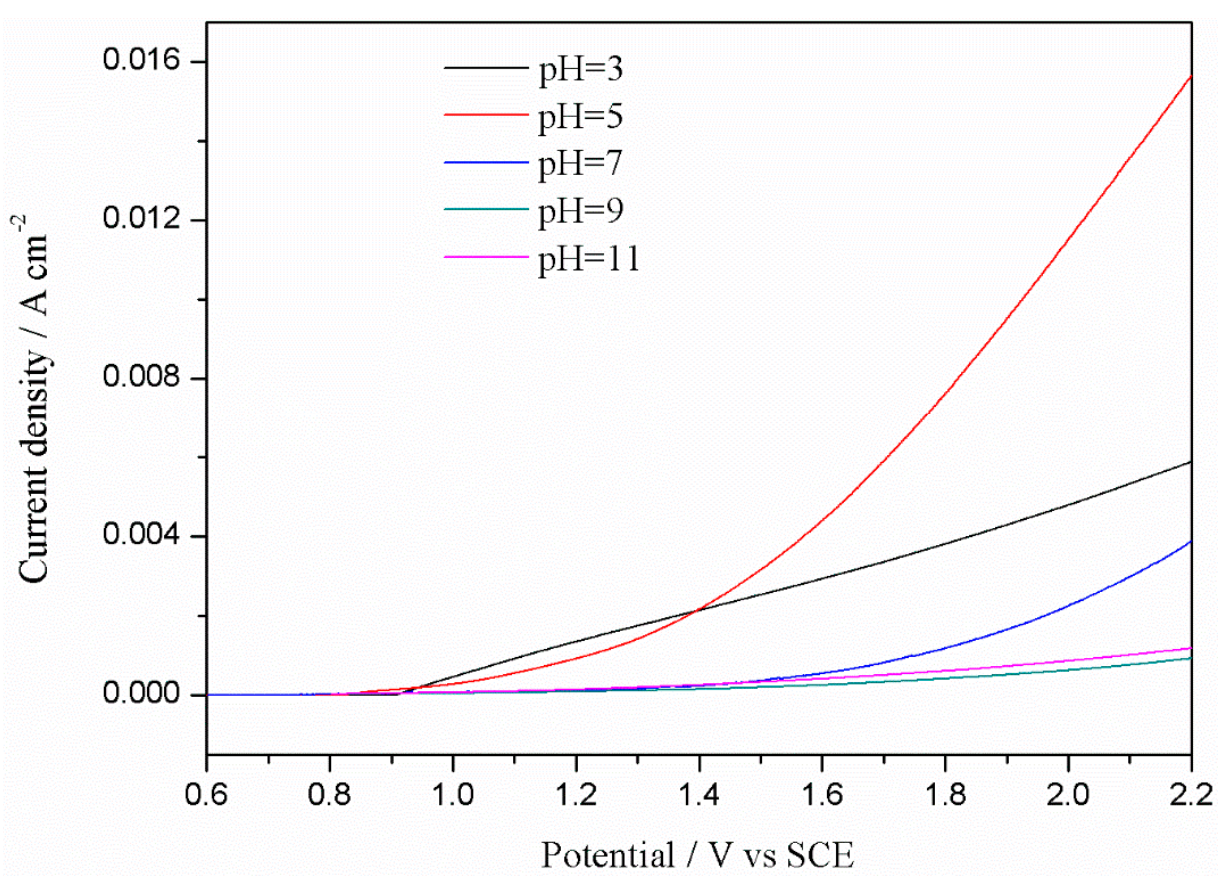

Figure 6. Linear sweep voltammetry (LSV) curves in different $\mathrm{pH}$ solutions of the $150 \mu \mathrm{m}$ porous $\mathrm{Ti} / \mathrm{SnO}_{2}-\mathrm{Sb}_{2} \mathrm{O}_{3} / \mathrm{PbO}_{2}$ electrode in $0.5 \mathrm{~mol} \mathrm{~L}^{-1} \mathrm{H}_{2} \mathrm{SO}_{4}$ solution at a scan rate of $5 \mathrm{mV} \mathrm{s}^{-1}$.

\subsection{Electrocatalytic Oxidation of Chloride Ions}

\subsubsection{Effect of Pore Size}

With the electrolysis time fixed at $4 \mathrm{~h}$, the electrode plate spacing at $1.0 \mathrm{~cm}$, the $\mathrm{NaCl}$ concentration at $10 \mathrm{~g} \mathrm{~L}^{-1}$, and the current density at $100 \mathrm{~mA} \mathrm{~cm}^{-2}$, the chloride ion removal ratios of the electrodes were determined to explore the optimal electrode pore size among three different kinds of porous electrodes in $\mathrm{NaCl}$ solution. As shown in Figure 7a, the optimal pore size of porous $\mathrm{Ti} / \mathrm{SnO}_{2}-\mathrm{Sb}_{2} \mathrm{O}_{3} / \mathrm{PbO}_{2}$ electrode is $150 \mu \mathrm{m}$ after $4 \mathrm{~h}$, and the removal ratio of chloride ions is $92.8 \%$, which confirms that the $150 \mu \mathrm{m}$ pore size electrode performs best among the above three different kinds of porous electrodes. In addition, the effect of removing chloride ions from the $150 \mu \mathrm{m}$ porous $\mathrm{Ti} / \mathrm{SnO}_{2}-\mathrm{Sb}_{2} \mathrm{O}_{3}$ electrode and porous $\mathrm{Ti} / \mathrm{SnO}_{2}-\mathrm{Sb}_{2} \mathrm{O}_{3} / \mathrm{PbO}_{2}$ electrode is also compared. It can be seen from Figure $7 \mathrm{~b}$ that the porous electrode with $\mathrm{PbO}_{2}$ coating has a much better effect on removing chloride ions than the electrode without $\mathrm{PbO}_{2}$ coating. The reason for this improvement is that the stability and the oxygen evolution potential of the porous $\mathrm{Ti} / \mathrm{SnO}_{2}-\mathrm{Sb}_{2} \mathrm{O}_{3} / \mathrm{PbO}_{2}$ electrode are further improved by the addition of the $\mathrm{PbO}_{2}$ coating, which is beneficial for achieving an increased removal ratio of chloride ions.
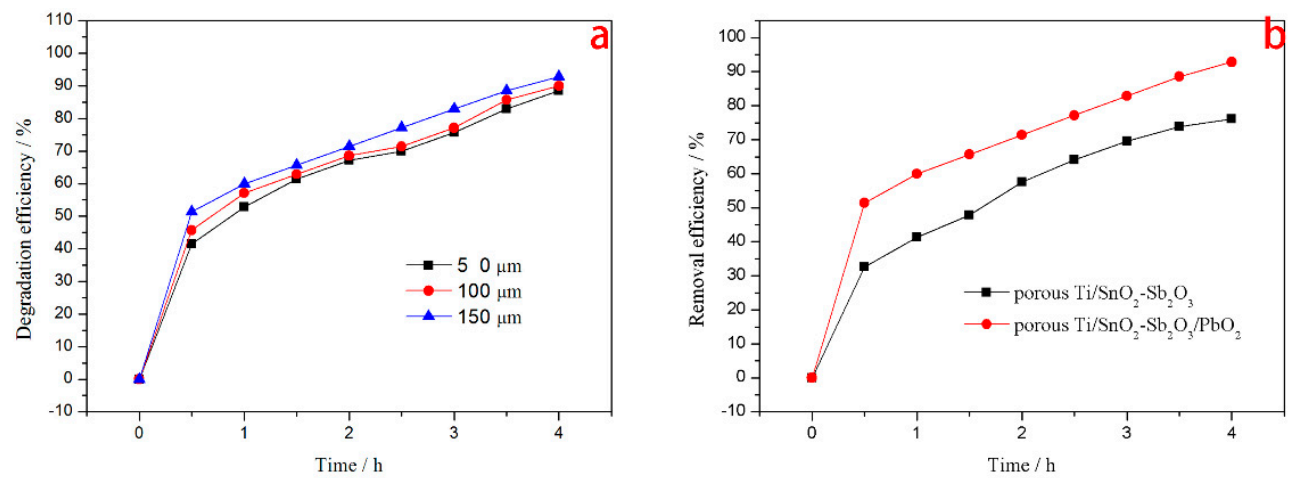

Figure 7. (a) Effect of pore size on chloride ion removal efficiency; (b) chloride ion removal efficiency as observed with $150 \mu \mathrm{m}$ porous $\mathrm{Ti} / \mathrm{SnO}_{2}-\mathrm{Sb}_{2} \mathrm{O}_{3}$ and $150 \mu \mathrm{m}$ porous $\mathrm{Ti} / \mathrm{SnO}_{2}-\mathrm{Sb}_{2} \mathrm{O}_{3} / \mathrm{PbO}_{2}$ electrodes. 


\subsubsection{Effect of Initial $\mathrm{NaCl}$ Concentration}

Related studies have shown that the initial ion concentration can affect the chloride ion removal ratio and cell voltage. As shown in Figure 8, with the electrolysis time fixed at $4 \mathrm{~h}$, the plate spacing at $1.0 \mathrm{~cm}$, and the current density at $100 \mathrm{~mA} \mathrm{~cm}^{-2}$, the removal ratio of chloride ions and the cell voltage both decrease as the $\mathrm{NaCl}$ concentration is increased. The reason for this effect is that the conductivity is increased and the electrical resistance decreased as the $\mathrm{NaCl}$ concentration is increased [1]. In addition, it could be seen from the figure that the $150 \mu \mathrm{m}$ porous $\mathrm{Ti} / \mathrm{SnO}_{2}-\mathrm{Sb}_{2} \mathrm{O}_{3} / \mathrm{PbO}_{2}$ electrode has a superior removal effect on chloride ions at low concentrations. Therefore, considering the combined effects of the removal ratio chloride ions and the cell voltage, $10 \mathrm{~g} \mathrm{~L}^{-1} \mathrm{NaCl}$ solution were selected as the following study.
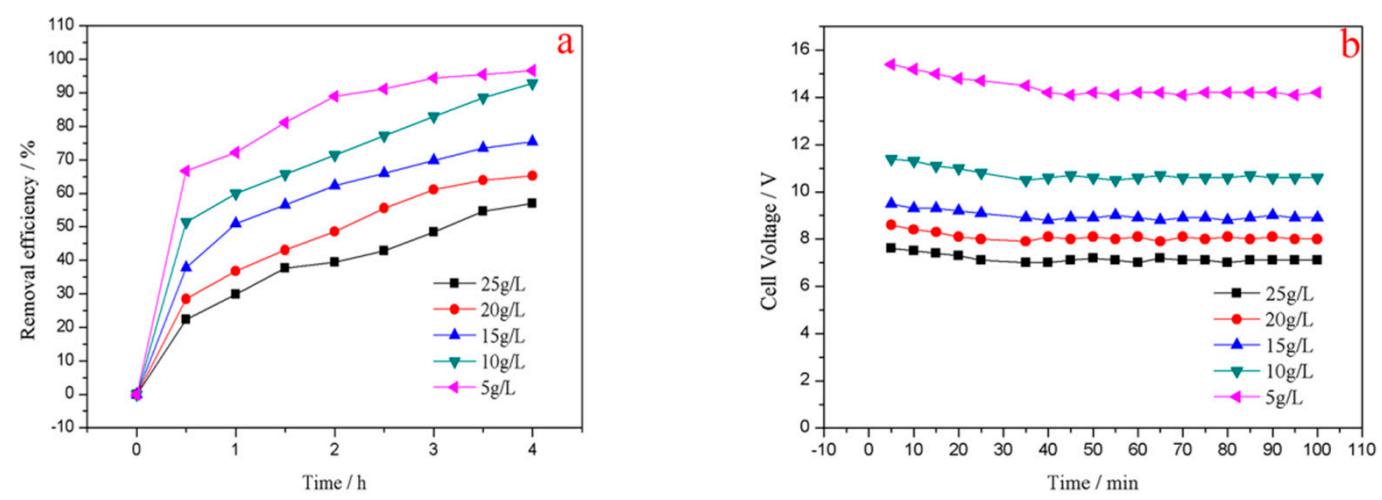

Figure 8. (a) Chloride ions removal efficiency under various initial $\mathrm{NaCl}$ concentration; (b) change in cell voltage under various initial $\mathrm{NaCl}$ concentrations.

\subsubsection{Effect of Current Density}

With the electrolysis time at $4 \mathrm{~h}$, the optimal reaction current density was determined for $150 \mu \mathrm{m}$ porous $\mathrm{Ti} / \mathrm{SnO}_{2}-\mathrm{Sb}_{2} \mathrm{O}_{3} / \mathrm{PbO}_{2}$ electrodes. As shown in Figure 9, with a $150 \mu \mathrm{m}$ electrode, a $\mathrm{NaCl}$ concentration $10 \mathrm{~g} \mathrm{~L}^{-1}$, and the electrode plate spacing $1.0 \mathrm{~cm}$, the removal ratio of chloride ions almost reached an upper limit at $125 \mathrm{~mA} \mathrm{~cm}^{-2}$ within $4 \mathrm{~h}$. Current densities higher than $125 \mathrm{~mA} \mathrm{~cm}^{-2}$, tended to damage the electrodes, resulting in reduced electrode lifetimes. So, it could be concluded that $125 \mathrm{~mA} \mathrm{~cm}^{-2}$ is the optimal current density.

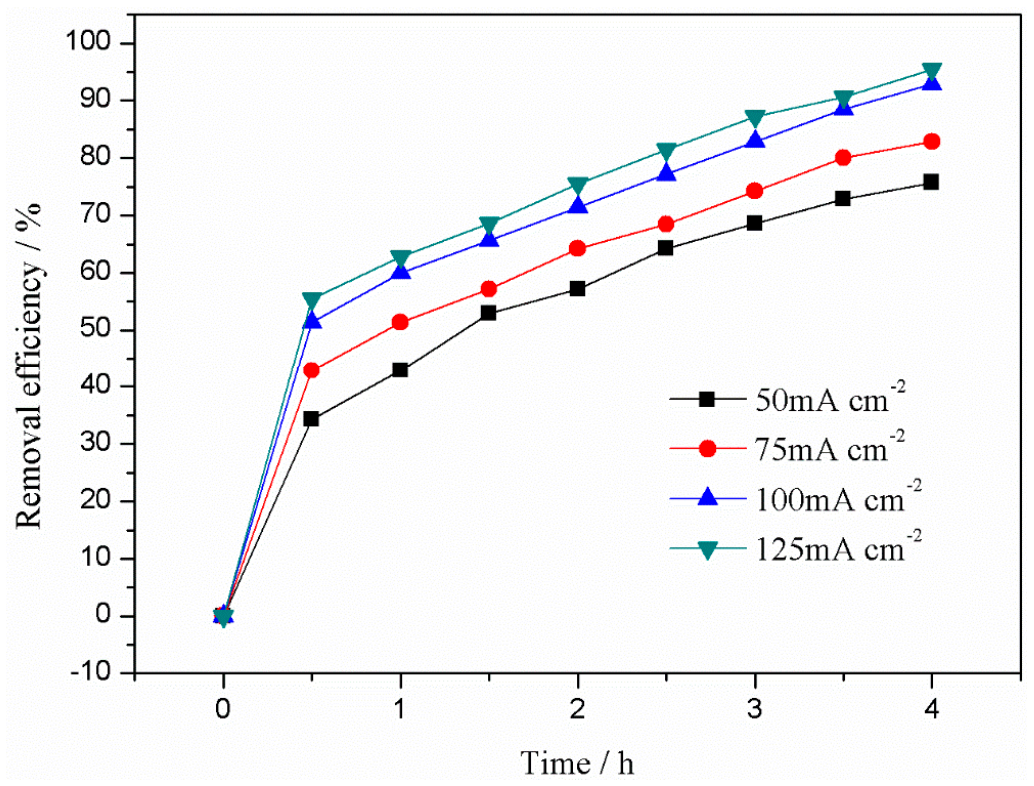

Figure 9. Chloride ion removal efficiency under various current densities. 


\subsubsection{Effect of Initial $\mathrm{pH}$}

As can be seen in Figure 10, with the $150 \mu$ m electrode, the $\mathrm{NaCl}$ concentration $10 \mathrm{~g} \mathrm{~L}^{-1}$, the electrode plate spacing $1.0 \mathrm{~cm}$, and the current density $125 \mathrm{~mA} \mathrm{~cm}^{-2}$, the removal ratio of chloride ions is shown under the $\mathrm{pH}$ from 3 to 11 . The solution of $\mathrm{pH}=3$ and $\mathrm{pH}=5$ was prepared by adding diluted concentrated sulfuric acid, and the solution of $\mathrm{pH}=9$ and $\mathrm{pH}=11$ was prepared by adding a diluted sodium hydroxide solution. It can be seen from the figure when the initial $\mathrm{pH}$ is the weak acidity, weak alkali, or neutral conditions, and the removal ratio of chloride ions is very effective, the removal ratio could reach $98.5 \%$ at $\mathrm{pH}=9$. In addition, the porous $\mathrm{Ti} / \mathrm{SnO}_{2}-\mathrm{Sb}_{2} \mathrm{O}_{3} / \mathrm{PbO}_{2}$ electrode has a good removal effect over the whole range of $\mathrm{pH}$ values.

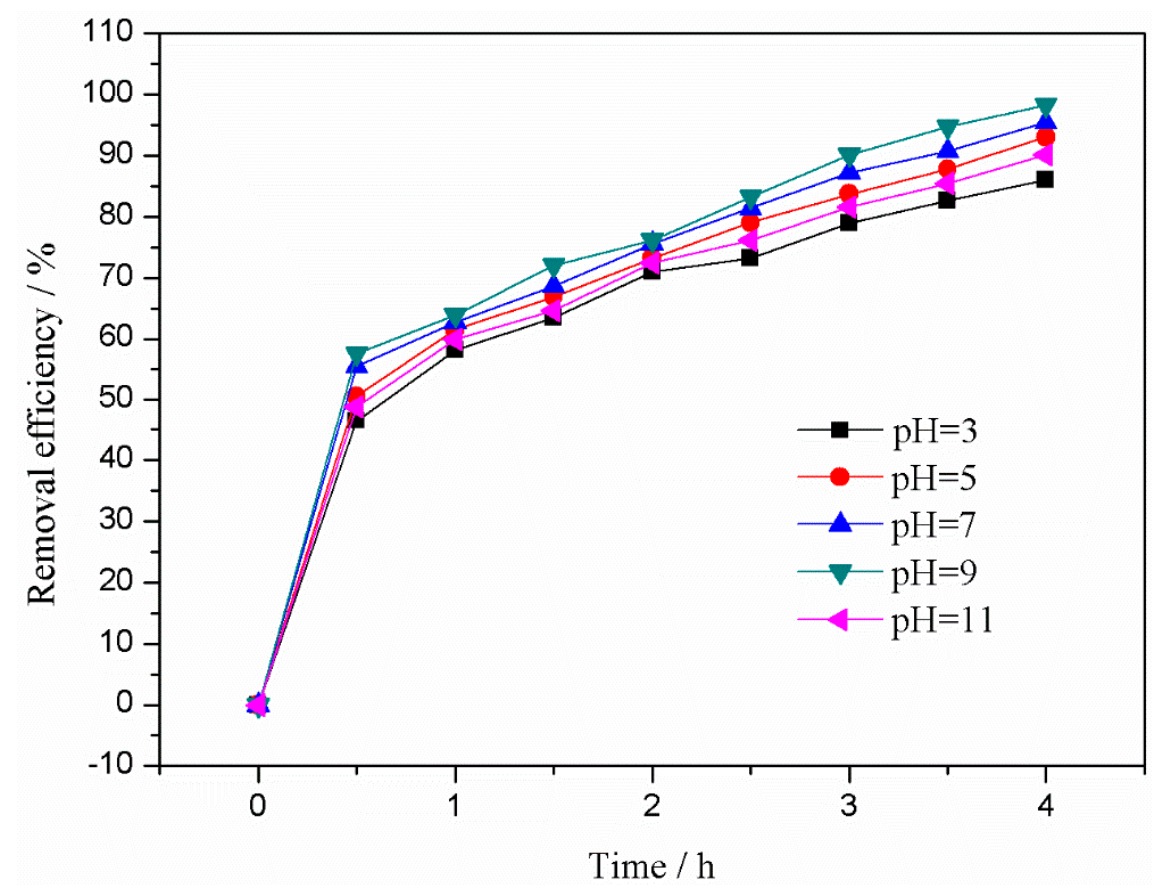

Figure 10. Chloride ion removal efficiency as a function of initial $\mathrm{pH}$ value.

\subsubsection{Effect of Electrode Plate Spacing}

Through the previous work, it was found that a change in the spacing between cathode and anode plates would cause a change in the cell voltage, which will impact the energy consumption of the whole process. As can be seen from Figure 11, the cell voltage at a current density of $125 \mathrm{~mA} \mathrm{~cm} \mathrm{c}^{-2}$ is about $11.7 \mathrm{~V}$, when the spacing between both the plates is $1.0 \mathrm{~cm}$ and when the $150 \mu \mathrm{m}$ electrode is operated in a $\mathrm{NaCl}$ solution with a concentration of $10 \mathrm{~g} \mathrm{~L}^{-1}$ and at an initial $\mathrm{pH}=9$. Reduction of the plate spacing to $0.75 \mathrm{~cm}$ lowers the cell voltage to about $10.4 \mathrm{~V}$; a further reduction to $9.4 \mathrm{~V}$ occurs when the plate spacing is reduced to $0.5 \mathrm{~cm}$. Therefore, it can be seen that the voltage decreases as the spacing between both plates is reduced. A reduction in the spacing of the anode and cathode plates therefore can lower the cell voltage and thereby the power consumption. 


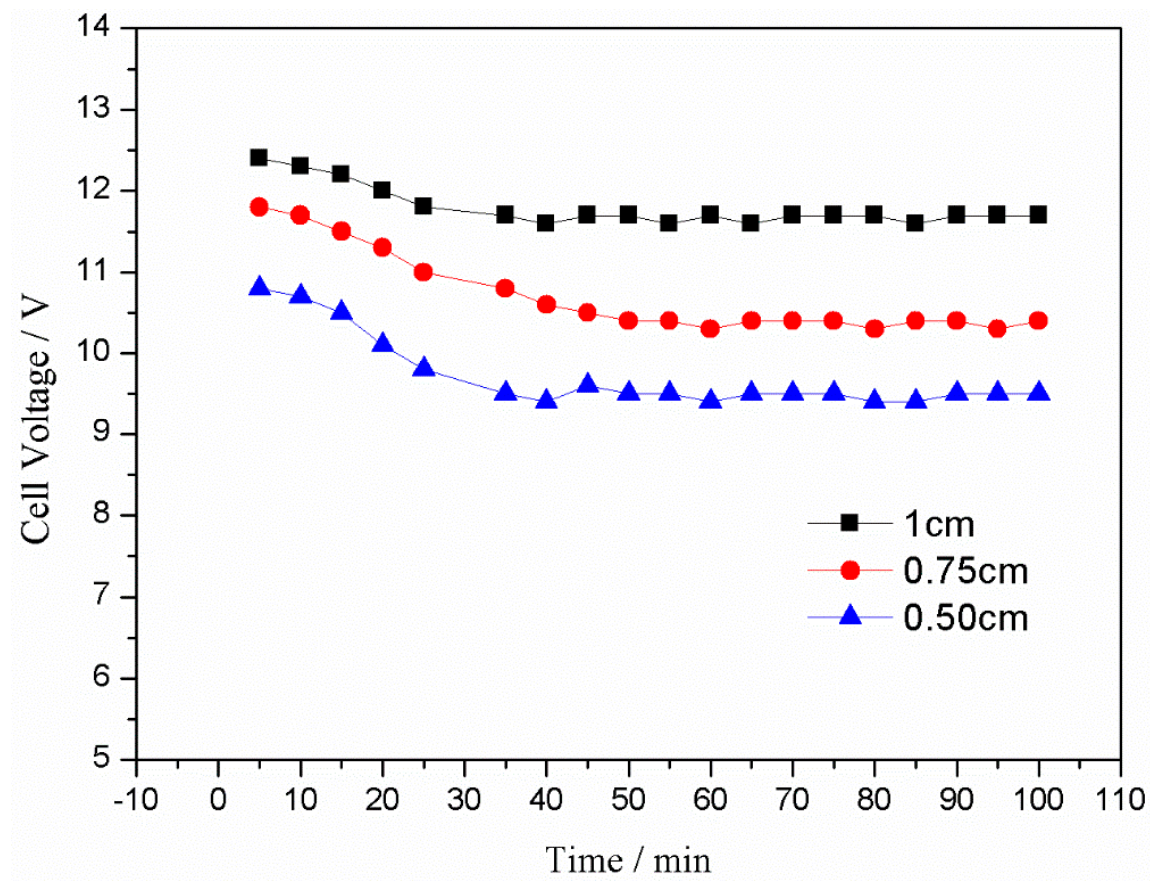

Figure 11. Change in cell voltage with electrode plate spacing.

\subsubsection{Number of Cycles}

With the $150 \mu \mathrm{m}$ electrode, a $\mathrm{NaCl}$ concentration of $10 \mathrm{~g} \mathrm{~L}^{-1}$, an initial $\mathrm{pH}=9$, a current density $125 \mathrm{~mA} \mathrm{~cm}^{-2}$, and the spacing between plates $0.5 \mathrm{~cm}$, Figure 12a shows the change in removal ratio of chloride ions of the porous electrode after repeating the removal process under optimal conditions for ten times. It can be seen that the removal ratio of chloride ions decreases after 10 times. However, the removal ratio of chloride ions of the porous $\mathrm{Ti} / \mathrm{SnO}_{2}-\mathrm{Sb}_{2} \mathrm{O}_{3} / \mathrm{PbO}_{2}$ electrode is still more than $90 \%$, which indicates that the porous $\mathrm{Ti} / \mathrm{SnO}_{2}-\mathrm{Sb}_{2} \mathrm{O}_{3} / \mathrm{PbO}_{2}$ electrode has great advantages in stability. In addition, Figure $12 b, c$ show the SEM and XRD patterns of the electrode after recycling, Figure 12c shows that the XRD spectrum of the electrode has not changed with the previous electrode after recycling, and Figure 12b shows that the $\mathrm{PbO}_{2}$ deposition coating of the electrode has suffered partial damage after recycling. By zooming 4000 times, it is found that the $\mathrm{PbO}_{2}$ deposition coating has developed many cracks, and thus it may be suspected that the reduction in removal rate might be related to these cracks.
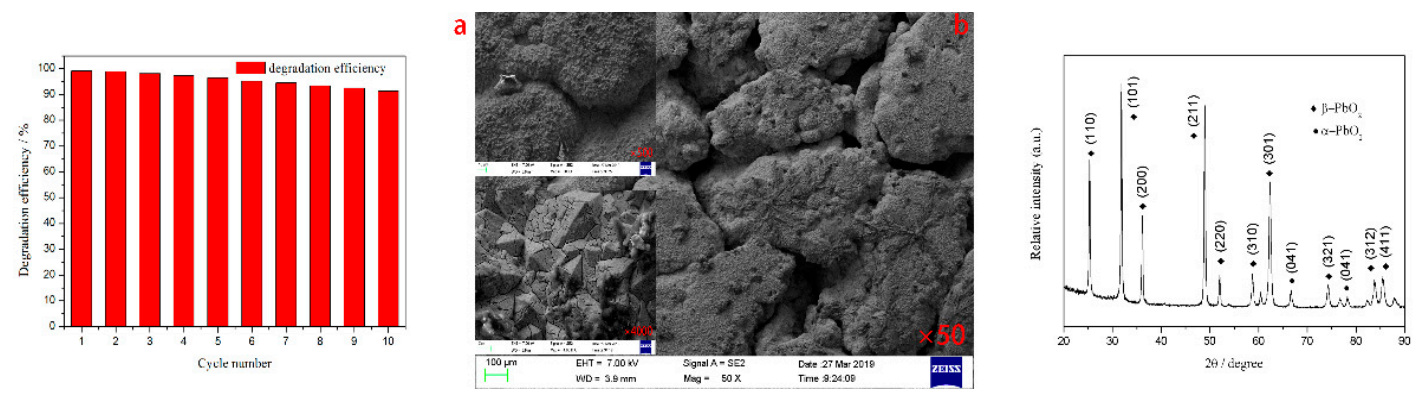

Figure 12. (a) Change in chloride removal rate of a porous $\mathrm{Ti} / \mathrm{SnO}_{2}-\mathrm{Sb}_{2} \mathrm{O}_{3} / \mathrm{PbO}_{2}$ electrode during ten successive removal cycles; (b) Scanning electron microscopy (SEM) pattern of the porous $\mathrm{Ti} / \mathrm{SnO}_{2}-\mathrm{Sb}_{2} \mathrm{O}_{3} / \mathrm{PbO}_{2}$ electrode after recycling; (c) X-ray diffraction (XRD) pattern of the porous $\mathrm{Ti} / \mathrm{SnO}_{2}-\mathrm{Sb}_{2} \mathrm{O}_{3} / \mathrm{PbO}_{2}$ electrode after recycling. 


\subsubsection{Mechanism of Removing Chloride Ions}

During the experiment, the sodium chloride solution was poured into the electrolytic cell. The chlorine evolution reaction and other side reactions mainly occurred at the anode. The hydrogen evolution reaction and other side reactions mainly occurred at the cathode. The chloride ions formed chlorine gas at the anode and the produced chlorine gas was absorbed in the absorption tank, which in turn resulted in the removal of chloride ions.

Anode reaction:

$$
\begin{gathered}
2 \mathrm{Cl}^{-}-2 \mathrm{e}^{-} \rightarrow \mathrm{Cl}_{2} \uparrow \\
4 \mathrm{OH}^{-}-4 \mathrm{e}^{-} \rightarrow 2 \mathrm{H}_{2} \mathrm{O}+\mathrm{O}_{2} \uparrow
\end{gathered}
$$

Cathode reaction:

$$
\begin{gathered}
2 \mathrm{H}_{2} \mathrm{O}+2 \mathrm{e}^{-} \rightarrow 2 \mathrm{OH}^{-}+\mathrm{H}_{2} \uparrow \\
\mathrm{ClO}^{-}+2 \mathrm{H}_{2} \mathrm{O}+2 \mathrm{e}^{-} \rightarrow 2 \mathrm{OH}^{-}+\mathrm{Cl}^{-}
\end{gathered}
$$

Side reaction in solution:

$$
\begin{gathered}
\mathrm{Cl}_{2}+2 \mathrm{OH}^{-} \rightarrow \mathrm{ClO}^{-}+\mathrm{Cl}^{-}+\mathrm{H}_{2} \mathrm{O} \\
\mathrm{Cl}_{2}+\mathrm{H}_{2} \mathrm{O} \rightarrow \mathrm{HClO}+\mathrm{H}^{+}+\mathrm{Cl}^{-} \\
\mathrm{HClO}+\mathrm{H}_{2} \mathrm{O} \rightarrow \mathrm{H}^{+}+\mathrm{ClO}^{-}
\end{gathered}
$$

It can be seen from the above reaction formulae that the side reaction (2) competes with the desired chloride removal reaction (1) for holes from the anode. Due to the high oxygen evolution potential of porous $\mathrm{Ti} / \mathrm{SnO}_{2}-\mathrm{Sb}_{2} \mathrm{O}_{3} / \mathrm{PbO}_{2}$ electrodes, reaction (2), however, is inhibited. With reaction (2) being inhibited, the generation of $\mathrm{OH}^{-}$ions at the cathode via reaction (3) will also be inhibited. Under alkaline conditions, side reactions (5)-(7) will tend to produce $\mathrm{ClO}^{-}$ions, which, in turn, will become converted into $\mathrm{Cl}^{-}$ions via reaction (4) and which will finally become removed by the main reaction (1). As previous studies have shown that the concentrations of hypochlorite and perchlorate ions which are generated in the electrolysis of sodium chloride solutions are actually quite small [21], side reactions (5)-(7) are not expected to make any major contribution to the overall chlorine removal process $[22,23]$. Overall, our considerations therefore reveal that porous $\mathrm{Ti} / \mathrm{SnO}_{2}-\mathrm{Sb}_{2} \mathrm{O}_{3} / \mathrm{PbO}_{2}$ electrodes can efficiently remove chloride ions from aqueous solutions, thus opening very broad application prospects.

\section{Conclusions}

In this paper, $150 \mu \mathrm{m}$ porous $\mathrm{Ti} / \mathrm{SnO}_{2}-\mathrm{Sb}_{2} \mathrm{O}_{3} / \mathrm{PbO}_{2}$ electrodes have been demonstrated to exhibit a good removal effect on chloride ions from $\mathrm{NaCl}$ solutions via the process of electrocatalytic oxidation. Factors that were found to influence the process of electrocatalytic oxidation were initial concentration, pore size, current density, initial $\mathrm{pH}$, electrode plate spacing, and the number of removal cycles. Removal ratios of chloride ions up to $98.5 \%$ were observed under the following conditions: initial concentration $10 \mathrm{~g} \mathrm{~L}^{-1}$, current density $125 \mathrm{~mA} \mathrm{~cm}^{-2}$, electrode plate pore size $150 \mu \mathrm{m}$, initial $\mathrm{pH}=9$, and electrode plate spacing $0.5 \mathrm{~cm}$. Under these conditions, the porous electrodes exhibited good stability. Physicochemical and electrochemical characterization results showed that porous $\mathrm{Ti} / \mathrm{SnO}_{2}-\mathrm{Sb}_{2} \mathrm{O}_{3} / \mathrm{PbO}_{2}$ electrodes had a high oxygen evolution potential. Overall, it appears that porous $\mathrm{Ti} / \mathrm{SnO}_{2}-\mathrm{Sb}_{2} \mathrm{O}_{3} / \mathrm{PbO}_{2}$ electrodes can play an important role in the electrocatalytic oxidation of chloride ions in water, thus opening prospects for a wide range of applications. 
Author Contributions: Conceptualization, K.X.; Data curation, P.C.; Formal analysis, W.G.; Project administration, P.Y.; Resources, Y.L.; Writing-review \& editing, J.P.

Funding: The authors declare no funding.

Acknowledgments: The study was supported by the college of chemistry and molecular sciences at Wuhan University.

Conflicts of Interest: The authors declare no conflict of interest.

\section{References}

1. Cui, L.; Li, G.P.; Li, Y.Z.; Yang, B.; Zhang, L.Q.; Dong, Y.; Ma, C.Y. Electrolysis-electrodialysis process for removing chloride ion in wet flue gas desulfurization wastewater (DW): Influencing factors and energy consumption analysis. Chem. Eng. Res. Des. 2017, 123, 240-247. [CrossRef]

2. Abdel-Wahab, A.; Batchelor, B. Chloride removal from recycled cooling water using ultra-high lime with aluminum process. Water Environ. Res. 2002, 74, 256-263. [CrossRef] [PubMed]

3. Woolard, C.R.; Irvine, R.L. Biological treatment of hypersaline wastewater by a biofilm of halophific bacteria. Water Environ. Res. 1994, 66, 230-235. [CrossRef]

4. Vyrides, I.; Stuckey, D.C. Saline sewage treatment using a submerged anaerobic membrane reactor (SAMBR): Effects of activated carbon addition and biogas-sparging time. Water Res. 2009, 43, 933-942. [CrossRef] [PubMed]

5. Walha, K.; Amar, R.B.; Firdaous, L.; Quéméneur, F.; Jaouen, P. Brackish groundwater treatment by nanofiltration, reverse osmosis and electrodialysis in tunisia: Performance and cost comparison. Desalination 2007, 207, 95-106. [CrossRef]

6. Mansoor, K. New nanopore zeolite membranes for water treatment. Desalination 2010, 251, 176-180.

7. Shaw, W.A. Fundamentals of zero liquid discharge system design. Power 2011, 155, 56-63.

8. Lv, L.; Sun, P.D.; Gu, Z.Y.; Du, H.G.; Pang, X.J.; Tao, X.H.; Xu, R.F.; Xu, L.L. Removal of chloride ion from aqueous solution by $\mathrm{ZnAl}-\mathrm{NO}_{3}$ layered double hydroxides as anion-exchanger. J. Hazard. Mater. 2009, 161, 1444-1449. [CrossRef]

9. Li, H.S.; Chen, Y.H.; Long, J.Y.; Jiang, D.Q.; Liu, J.; Li, S.J.; Qi, J.Y.; Zhang, P.; Wang, J.; Gong, J.; et al. Simultaneous removal of thallium and chloride from a highly saline industrial wastewater using modified anion exchange resins. J. Hazard. Mater. 2017, 333, 179-185. [CrossRef]

10. Jiang, S.X.; Li, Y.N.; Bradley, P.L. A review of reverse osmosis membrane fouling and control strategies. Sci. Total Environ. 2017, 595, 567-583. [CrossRef]

11. Li, D.; Tang, J.Y.; Zhou, X.Z.; Li, J.S.; Sun, X.Y.; Shen, J.Y.; Wang, L.J.; Han, W.Q. Electrochemical degradation of pyridine by $\mathrm{Ti} / \mathrm{SnO}_{2}-\mathrm{Sb}$ tubular porous electrode. Chemosphere 2016, 149, 49-56. [CrossRef] [PubMed]

12. Yang, K.; Lin, H.; Liang, S.T.; Xie, R.Z.; Lv, S.H.; Niu, J.F.; Chen, J.; Hu, Y.Y. A reactive electrochemical filter system with an excellent penetration flux porous $\mathrm{Ti} / \mathrm{SnO}_{2}-\mathrm{Sb}$ filter for efficient contaminant removal from water. RSC Adv. 2018, 8, 13933-13944. [CrossRef]

13. An, H.; Li, Q.; Tao, D.J.; Cui, H.; Xu, X.T.; Ding, L.; Sun, L.; Zhai, J.P. The synthesis and characterization of $\mathrm{Ti} / \mathrm{SnO}_{2}-\mathrm{Sb}_{2} \mathrm{O}_{3} / \mathrm{PbO}_{2}$ electrodes: The influence of morphology caused by different electrochemical deposition time. Appl. Surf. Sci. 2011, 258, 218-224. [CrossRef]

14. Ding, H.Y.; Feng, Y.J.; Liu, J.F. Preparation and properties of $\mathrm{Ti} / \mathrm{SnO}_{2}-\mathrm{Sb}_{2} \mathrm{O}_{5}$ electrodes by electrodeposition. Mater. Lett. 2007, 61, 4920-4923. [CrossRef]

15. Zhao, W.; Xing, J.T.; Chen, D.H.; Bai, Z.L.; Xia, Y.S. Study on the performance of an improved $\mathrm{Ti} / \mathrm{SnO}_{2}-\mathrm{Sb}_{2} \mathrm{O}_{3} / \mathrm{PbO}_{2}$ based on porous titanium substrate compared with planar titanium substrate. RSC Adv. 2015, 5, 26530-26539. [CrossRef]

16. Zhao, W.; Xing, J.T.; Chen, D.H.; Jin, D.Y.; Shen, J. Electrochemical degradation of Musk ketone in aqueous solutions using a novel porous $\mathrm{Ti} / \mathrm{SnO}_{2}-\mathrm{Sb}_{2} \mathrm{O}_{3} / \mathrm{PbO}_{2}$ electrodes. J. Electroanal. Chem. 2016, 775, 179-199. [CrossRef]

17. Xing, J.T.; Chen, D.H.; Zhao, W.; Peng, X.L.; Bai, Z.L.; Zhang, W.W.; Zhao, X.X. Preparation and characterization of a novel porous Ti/ $\mathrm{SnO}_{2}-\mathrm{Sb}_{2} \mathrm{O}_{3}-\mathrm{CNT} / \mathrm{PbO}_{2}$ electrode for anodic oxidation of phenol wastewater. RSC Adv. 2015, 5, 53504-53513. [CrossRef]

18. Sun, J.R.; Lu, H.Y.; Lin, H.B.; Huang, W.M.; Li, H.D.; Lu, J.; Cui, T. Boron doped diamond electrodes based on porous Ti substrate. Mater. Lett. 2012, 83, 112-114. [CrossRef] 
19. Ishibashi, K.; Fujishima, A.; Watanabe, T.; Hashimoto, K. Detection of active oxidative species in $\mathrm{TiO}_{2}$ photocatalysis using the fluorescence technique. Electrochem. Commun. 2000, 2, 207-210. [CrossRef]

20. Zhang, W.L.; Lin, H.B.; Kong, H.S.; Lu, H.Y.; Yang, Z.; Liu, T.T. High energy density $\mathrm{PbO}_{2} /$ activated carbon asymmetric electrochemical capacitor based on lead dioxide electrode with three-dimensional porous titanium substrate. Int. J. Hydrogen Energy 2014, 39, 17153-17161. [CrossRef]

21. Neodo, S.; Rosestolato, D.; Ferro, S.; De Battisti, A. On the electrolysis of dilute chloride solutions: Influence of the electrode material on Faradaic efficiency for active chlorine, chlorate and perchlorate. Electrochim. Acta 2012, 80, 282-291. [CrossRef]

22. Duirk, S.E.; Desetto, L.M.; Davis, G.M. Transformation of Organophosphorus Pesticides in the Presence of Aqueous Chlorine: Kinetics, Pathways, and Structure-Activity Relationships. Environ. Sci. Technol. 2009, 43, 2335-2340. [CrossRef] [PubMed]

23. Cherney, D.P.; Duirk, S.E.; Tarr, J.C.; Collette, T.W. Monitoring the speciation of aqueous free chlorine from pH 1 to 12 with Raman spectroscopy to determine the identity of the potent low-pH oxidant. Appl. Spectrosc. 2006, 60, 764-772. [CrossRef] [PubMed]

(C) 2019 by the authors. Licensee MDPI, Basel, Switzerland. This article is an open access article distributed under the terms and conditions of the Creative Commons Attribution (CC BY) license (http://creativecommons.org/licenses/by/4.0/). 